Short Communication

\title{
Development of an Electrochemical Quartz Crystal Microbalance-Based Immunosensor for C-reactive protein determination
}

\author{
Kai Gao, Song Cui and Sibo Liu* \\ Department of Critical Care Medicine, Dalian municipal central hospital, Dalian City, Liaolin \\ Province, 116001, P.R. China \\ *E-mail: siboliu@yeah.net
}

doi: $10.20964 / 2018.01 .49$

Received: 14 September 2017 / Accepted: 6 November 2017 / Published: 16 December 2017

In terms of outcome prediction in patients with inflammation, albumin and C-reactive protein (CRP) at serum levels have been considered to constitute a practical and reliable scoring system. In the present work, highly sensitive detection of C-reactive protein (hs-CRP) was achieved via a new strategy using a quartz crystal microbalance (QCM) immunosensor. A linear relationship was found between the QCM response and CRP concentration $(0.04-30 \mu \mathrm{g} / \mathrm{mL})$, with a low limit of detection (LOD) maintained via an amplification process.

Keywords: Electrochemical quartz crystal microbalance; Immunosensor; Inflammation Marker; Creactive protein; Limit of detection

\section{$\underline{\text { FULL TEXT }}$}

(C) 2018 The Authors. Published by ESG (www.electrochemsci.org). This article is an open access article distributed under the terms and conditions of the Creative Commons Attribution license (http://creativecommons.org/licenses/by/4.0/). 